\title{
Distance and Intensity of Microclimatic Influence Provided by Urban Forest Typologies
}

\author{
Angeline Martini ${ }^{1}$, Daniela Biondi ${ }^{2}$, Antônio Carlos Batista ${ }^{2}$ \\ ${ }^{1}$ Departamento de Engenharia Florestal, Universidade Federal de Viçosa - UFV, Viçosa/MG, Brasil \\ ${ }^{2}$ Departamento de Engenharia Florestal, Universidade Federal do Paraná - UFPR, Curitiba/PR, Brasil
}

\begin{abstract}
The main goal of this study was to determine the radius and intensity of the influence that different urban forest typologies exert on their surroundings. Thus, three distinct areas were selected for each type of urban forest: Remaining Forest, Old Green Area, Modern Green Area, Street Trees and Isolated Trees. The influence of these typologies on the surrounding microclimate was determined by mobile transects, collecting data every $50 \mathrm{~m}$ from a total route of $500 \mathrm{~m}$ in an adjacent street. In general, the influence radius of the urban forest on its surroundings was $200 \mathrm{~m}$, while the Remaining Forest typology reached $250 \mathrm{~m}$. On average, the influence intensity of urban forest at a distance of $50 \mathrm{~m}$ was $0.66^{\circ} \mathrm{C}$, at $100 \mathrm{~m}$ it was $0.45^{\circ} \mathrm{C}$, at $150 \mathrm{~m}$ it was $0.34^{\circ} \mathrm{C}$, and at $200 \mathrm{~m}$ it was $0.30^{\circ} \mathrm{C}$, but each typology varied. All microclimate results were more pronounced in summer. We concluded that the urban forest exerts a significant climatic influence on its surroundings, regardless of the typology.
\end{abstract}

Keywords: urban microclimate, microclimatic benefit, afforestation. 


\section{INTRODUCTION}

Lack of vegetation is a major contributor to climate change in urban centers, and considering that plants provide regulatory and climate-enhancing properties, they are a key feature to ensure an ideal urban climate (Abreu, 2008). For this reason, several cities around the world are seeking to increase green areas or vegetation cover as a way to manage urban heat, while also improving beauty, biodiversity and recreational value (Adams \& Smith, 2014).

Linked to this issue, global climate change has imposed new challenges and an extra reason to optimize planning and management of urban green areas (Jim et al., 2015). This expansion in urban vegetation (which occurred in the last decade) creates a means to improve the landscape, livability, and environmental and economic conditions of cities, as well as the quality of life and health of their citizens (Jiang et al., 2015).

Among the various options to provide cooling for cities, the best documented is the creation of urban parks and green spaces, which have the potential to provide thermally comfortable environments and reduce vulnerability to thermal stress (Brown et al., 2015). In addition to creating these green spaces, planting more trees in cities helps to mitigate the effects of heat islands (Thundiyil, 2003), which is an important ecosystem role played by urban trees. Therefore, small, scattered green masses can play an important role in mitigating urban climates and their ecological, regional and global behavior (Nascimento \& Oliveira, 2011).

According to Gartland (2010), the microclimatic benefit provided by vegetation is due to two main factors: shading and evapotranspiration. This is because the shade that trees provide for buildings, pavements and people protect them from the heat of the sun, keeping these surfaces cooler and thereby reducing heat transferred by these surfaces to the air above. On the other hand, evapotranspiration uses solar energy to evaporate water, which prevents this energy from being used to produce heat and warm up the city, keeping air temperatures lower during the day.

Trees can be excellent natural air conditioners (among other functions), and vegetation stands out as a fundamental element to minimize the effects of climate change caused by human action, promoting air cooling, increased relative humidity and ventilation changes (Dimoudi \& Nikolopoulou, 2003). Thus, when vegetation is well-distributed, the energy balance of the entire city can be modified by the addition of more evaporative surfaces. The absorbed radiation is then dissipated as latent heat and urban temperatures can be reduced (Yu \& Hien, 2006).

Studies have been focused on evaluating urban vegetation, especially in the context of sustainability, accelerating urbanization and quality of life (Raskovic \& Decker, 2015). The various functions that trees play in cities, their value, costs, benefits and their own diverse influences on urban areas have been widely discussed (Donovan \& Butry, 2010). In this context, the objective of the present research was to determine the distance and intensity of the influence that different typologies of urban forest play on their surroundings, and which typology provides greater microclimatic benefits.

\section{MATERIAL AND METHODS}

This study was developed in the city of Curitiba, capital of the state of Paraná, located in the southern region of Brazil. According to the Köppen classification, the climate in Curitiba is type $\mathrm{Cfb}$, being humid subtropical and mesothermic without a dry season, cool summers, and winters with frequent frosts and occasional snow. The summer is warm (with average temperatures of $19.7^{\circ} \mathrm{C}$ ) and moderate winter $\left(13.4^{\circ} \mathrm{C}\right.$ on average) with some days being more severe. Average annual precipitation is $1,419.91 \mathrm{~mm}$ with a non-fixed dry season between autumn and winter (IPPUC, 2011).

In order to carry out this study, areas that represented the most frequent urban forest typologies in the city were selected: Remaining Forest, Old Green Area (groupings of trees planted with eclectic landscaping), Modern Green Area (groupings of trees planted with modern landscaping), Street Trees (tree groupings that follow the road system), Isolated Trees (a single arboreal individual planted in the road system in a spaced manner).

In order to provide representativeness, three areas for each type of urban forest were selected totaling 15 monitoring sites, restricted to the central portion of the city (Figure 1): Parque Natural Municipal Barigüi, Bosque Gutierrez and Bosque João Paulo II (Remaining forest), Passeio Público, Praça Eufrásio Correia and Praça Carlos Gomes (Old Green Area), 


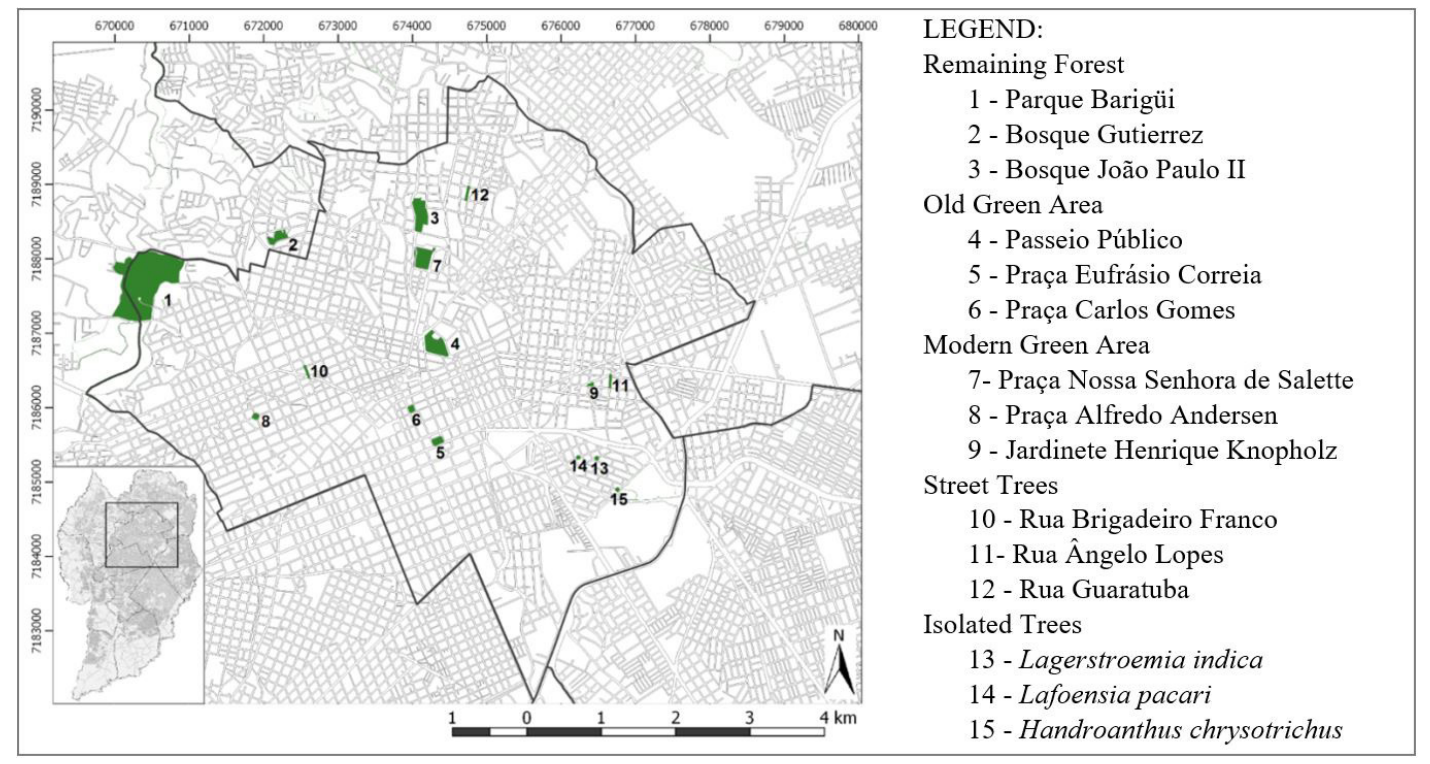

Figure 1. Monitoring sites for microclimate analysis in the city of Curitiba-PR.

Praça Nossa Senhora de Salette, Praça Alfredo Andersen and Jardinete Henrique Knopholz (Modern Green Area), Rua Ângelo Lopes, Rua Brigadeiro Franco and Rua Guaratuba (Street Trees), Lagerstroemia indica L. located at Rua Sant'Ana n. 395, Lafoensia pacari A.St.-Hil. located at Rua Brasílio Itiberê $\mathrm{n}^{\circ} .295$ and Handroanthus chrysotrichus (Mart. ex A.DC.) Mattos located at Rua Cel. João da Silva Sampaio nº 648 (Isolated Tree).

Analysis of the typologies' influence on their immediate surroundings was carried out by data collection through mobile transects in each of the selected urban forest typologies. This method consists of collecting meteorological information from equipment in continuous movement. To do so, an adjacent street at each urban forest typology was selected, which allowed for a $500 \mathrm{~m}$ walking route. We sought to select streets with similar characteristics and with the same geographical direction (East-West). For the Street Tree typology, the walking direction was the same as the direction of the tree-lined street (North-South), and for isolated trees the distance traveled was $50 \mathrm{~m}$. This distance was reduced due to the impossibility of ensuring that other urban elements in addition to the tree in question could/might interfere with meteorological data (including other trees).

The mobile transect traversed was defined considering that it should be traveled in a short time, minimizing the effects of the variable radiation intensities produced by the variation of the apparent height of the sun, avoiding the need to correct the data according to the measurement period (Leal et al., 2011). In addition, $500 \mathrm{~m}$ was defined to avoid interference from urban elements, including other forms of urban forest.

The influence of the urban forest typologies on their immediate surroundings was analyzed on different days due to the availability of equipment. Thus, the meteorological data of one of the selected areas were collected on each day. This procedure was repeated in the summer (February and March) and in the winter (July and August). The collection days varied according to the meteorological conditions of the day due to the need for clear skies during data collection time between 12 and 1 p.m. (corrected to 1 and 2 p.m. due to summer day-light savings). It should be noted that the hours close to noon are the ideal occasions to discriminate between the various types of micro-scale coverage (Huang et al., 2008).

For data collection, two previously calibrated $4200 \mathrm{Kestrel}^{\circledR}$ mini weather stations were used, kept at an approximate height of $1.50 \mathrm{~m}$. One mini-station remained under the care of one researcher at the urban forest typology center, and the other was used in the mobile transect walked by another researcher. The route started on the fragment border, extending along the streets or avenues until reaching a distance of 500 meters, and four repetitions were performed. 
Meteorological data were simultaneously collected between the equipment located within the urban forest typology and the equipment used in the mobile transect, as they were programmed to collect information at every minute with the same walking rhythm standardized throughout the course, and the distance between the collected points was $50 \mathrm{~m}$. A 10-second pause was made at each point (every $50 \mathrm{~m}$ ) before the next collection in order to stabilize the data. These procedures were validated by Martini et al. (2014), who confirmed that this is an adequate methodology for this type of analysis.

The mobile transect traversed by the researcher was recorded in its entirety with the aid of a Sony Cyber-shot digital camera coupled to a cap in order to clarify possible future doubts arising from data processing. Wind direction was determined at the beginning of each repetition by observing the movement of a tape coupled to the mini-station, both in the equipment that remained static within the study area and in the equipment used in the mobile transect.

All the trajectories in the streets adjacent to the selected areas were characterized in terms of the presence of vegetation at the end of meteorological data collection, as well as for the urban structures relevant to the research (street and sidewalk width).

Data collected using the mobile transect method allowed us to analyze three variables: air temperature $\left({ }^{\circ} \mathrm{C}\right)$, relative humidity $(\%)$ and wind speed $(\mathrm{m} / \mathrm{s})$. With this data, it was possible to analyze the influence of different urban forest typologies on the microclimate of the immediate environment.

The averages of the meteorological variables obtained from the four replications were then calculated at each spacing point. Therefore, a graph with the average temperature and relative humidity values obtained along the route for each typology was plotted. The values from within the selected areas are also presented on this same graph, consistent with the observation time.

In order to determine the influence distance, the point showing a temperature drop (or increase of relative humidity) without an apparent explanation (without the influence of other elements, such as trees, buildings or vehicles) was determined as the limit. Thus, the point prior to this event (temperature drop or increase of relative humidity) was considered the final influence distance of the area in question. The graphs were plotted for summer and winter seasons together and also separately for each season.

The influence intensity of the different urban forest typologies on the immediate environment was also calculated from the differences in the meteorological data found within the typology and in the mobile transect, for each spacing distance. The greatest difference in each typology was established based on the average from the three highest values found across all distances. The difference found in each distance was then subtracted from this value until reaching the influence distance. The results are presented in graphs, with summer and winter seasons together and also separately for each season.

\section{RESULTS AND DISCUSSION}

\subsection{Influence distance on the immediate environment}

In the analysis performed to determine the influence distance that the different urban forest typologies exert, it was found that the distance varies according to typology (Figure 2).

In general, the influence distance that the urban forest exerted on its surroundings for both temperature and relative humidity was $200 \mathrm{~m}$, except for the Isolated Tree typology. No conclusive results were found for wind speed.

It can be noted that Remaining Forests have a microclimatic influence on the surroundings up to a distance of $250 \mathrm{~m}$ from the edge, while Modern Green Areas reach a distance of $200 \mathrm{~m}$. These values are representative for both temperature and relative humidity. Old Green Areas had an influence on temperature reaching $150 \mathrm{~m}$, while it was $100 \mathrm{~m}$ for relative humidity. The influence of Street Trees on temperature was up to $150 \mathrm{~m}$, and relative humidity up to $200 \mathrm{~m}$. The influence for the Isolated Tree typology was up to $10 \mathrm{~m}$ for temperature and $25 \mathrm{~m}$ for relative humidity. Wind speed was a variable with too much oscillation to be determined; however, the values tend to be lower within the typology.

According to Mascaró \& Mascaró (2009), the incidence of wind under the trees decreases the differences in temperature and relative humidity of the air between shaded and sunny areas. This effect is 


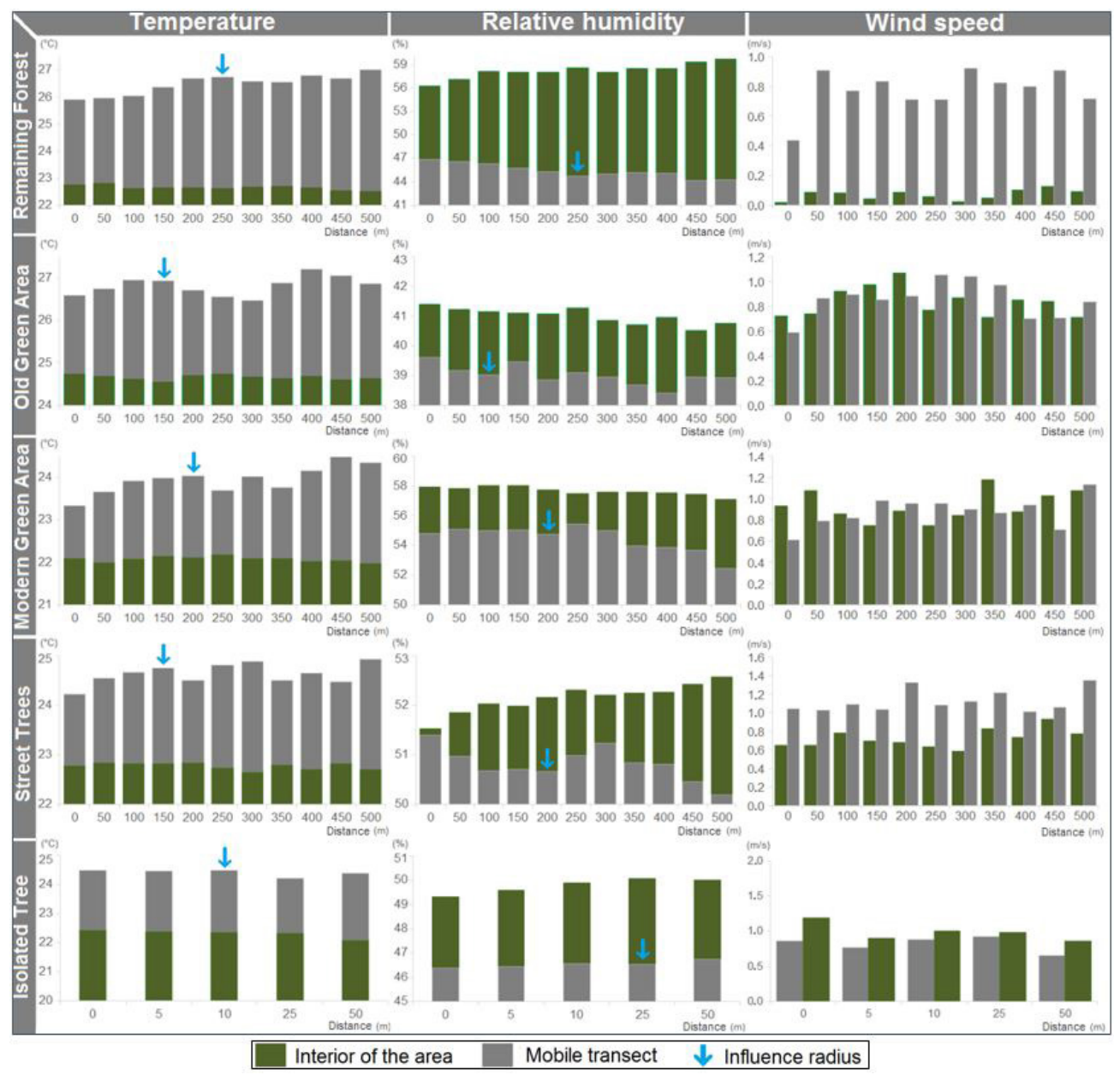

Figure 2. Microclimate within the urban forest typologies and in the mobile transect traversed for analysis of the influence distance.

verified when the wind speed is greater than $1.5 \mathrm{~m} / \mathrm{s}$, which was not found in any of the observations of the present study. Moreover, Giralt (2006) states that when wind speeds are low, the temperature mostly results from the solar thermal gains of the site/area. In this situation, the solar radiation that reaches the terrestrial surface is received in a different way, depending on the type of soil, vegetation, topography and altitude. However, when wind speeds are high, the influence of local factors on air temperature is much lower.

Wind direction is perhaps the most important factor to be analyzed to determine the influence distance of the urban forest. For this reason we sought to standardize the same geographic direction (east-west) of the selected streets to carry out the route, consistent with the direction of the most frequent winds in the city. However, as this is a very variable meteorological element, wind direction was reassessed before each walking repetition.

The results regarding the influence distance found in this study reflect the influence of urban forest typologies against the direction of the wind, meaning that they express the direction with the least influence of the study areas; this occurred in $77 \%$ of the observations. However, in some situations the mobile transect was carried out with the wind, such as at Bosque Gutierrez and Jardinete Henrique Knopholz (in the summer), and at Praça Eufrásio Correia (in the winter), which overestimated the results due to favorable wind action. Also, the wind was classified as neutral at Rua Brigadeiro Franco and Ângelo Lopes (in the summer) and at Praça Alfredo Andersen and Jardinete Henrique Knopholz 
(in the winter), since its direction was perpendicular to the course. We emphasize that no more than one situation was collected with the wind or with neutral wind for each typology.

Studies in this direction have received considerable attention in recent years and several studies have already tried to determine the influence distance that certain green areas exert on their surroundings. One example is a study carried out in Tokyo (Japan), where researchers used numerical models to estimate the thermal effects of green areas on their surroundings and found a distance of approximately $300 \mathrm{~m}$ in the wind direction (Honjo \& Takakura, 1990). Another study, in Tel Aviv (Israel) also using numerical models, found that the cooling effect provided by eleven small green areas was very noticeable within a distance of up to $100 \mathrm{~m}$ from the border, being small but still significant (Shashua-Bar \& Hoffman, 2000).

In Petaling (Malaysia), a study was carried out to analyze the influence of three green areas on environmental cooling using satellite images that enable determining surface temperatures. The authors obtained clear results up to $500 \mathrm{~m}$ (Buyadi et al., 2014). In Beijing (China), values below $300 \mathrm{~m}$ on average were found using similar methodology in 30 green areas, although they reached up to $840 \mathrm{~m}$ in some situations (Lin et al., 2015).

Through long-term field measurements in Nagoya (Japan), it was found that cold air generated on the Heiwa urban park reached on average 200-300 m to the adjacent residential area, reaching up to $500 \mathrm{~m}$ in some cases (Hamada \& Ohta, 2010). Another study in the same park found that the commercial areas presented the smallest cooling distances, between 50 to $250 \mathrm{~m}$ (Hamada et al., 2013).

Based on local temperature observations, researchers in Seoul (South Korea) reported that the degree of cooling that a park can reach in its surroundings is $240 \mathrm{~m}$ (Lee et al., 2009); while an influence of approximately $400 \mathrm{~m}$ was observed in Bukit Batok and Clementi Woods parks in Singapore, (Yu \& Hien, 2006).

In Cuiabá (MT), Brazil, using the geostatistical method and mobile transects, it was found that the influence distance of an arboreal fragment on the thermal environment of a location can vary from 200 to
$500 \mathrm{~m}$, depending on the time of year and time of day, reaching higher values during the day and dropping at night (Barros, 2012).

In Curitiba, it had been previously observed by mobile transects that the influence of Bosque Capão da Imbuia on its surroundings during the fall was approximately $450 \mathrm{~m}$ (Biondi et al., 2011), and that the influence of the Remaining Forest from the Botanical Garden was observed up to $280 \mathrm{~m}$ in the winter (Martini et al., 2011).

An analysis performed by season made it possible to observe some variations between the results. The influence distance that the urban forest exerts on the temperature and relative humidity variables was up to $250 \mathrm{~m}$ in the summer and $150 \mathrm{~m}$ in the winter (Figures 3 and 4).

Only the Isolated Tree typology maintained the same distance of microclimatic influence in the summer and winter $(10 \mathrm{~m})$ for the temperature variable, while Old Green Areas had an increase of this distance in the winter (from 100 to $150 \mathrm{~m}$ ). All other typologies had their influence distances reduced in the winter, such as: the Remaining forest (250 to $50 \mathrm{~m}$ ), the Modern Green Area (200 to $150 \mathrm{~m}$ ) and the Street Trees (150 for $100 \mathrm{~m}$ ). This possibly occurred due to the species of some areas losing their leaves during winter.

For the relative humidity variable during the summer and winter, we found that the Remaining forest exerted an influence up to a distance of $250 \mathrm{~m}$ from the edge, the Old Green Area reached a distance of $100 \mathrm{~m}$ and Isolated Trees up to $25 \mathrm{~m}$. The Modern Green Area (from 200 to $100 \mathrm{~m}$ ) and Street Trees (from 200 to $100 \mathrm{~m}$ ) had their influence distances diminished in the winter.

During the winter the influence on the temperature decrease generally reaches shorter distances than in the summer. For relative humidity, the same influence distance is maintained throughout the seasons for the Remaining Forest, Old Green Area and Isolated Tree typologies. The distances are also shorter in the winter for the other typologies. Hamada \& Ohta (2010) also found that the effect of a green area in the residential environment (in Nagoya) was more pronounced during the summer. 


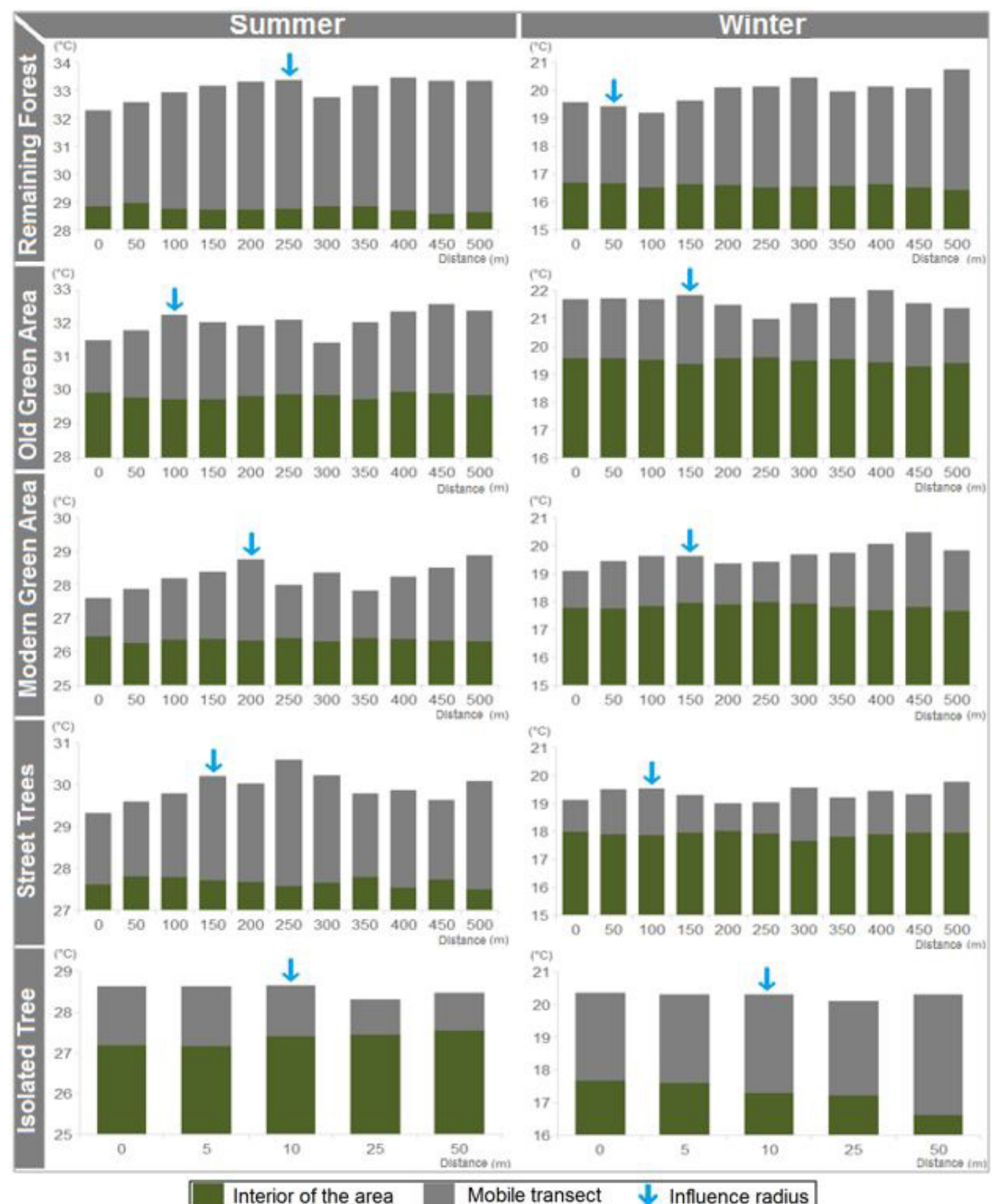

Figure 3. Air temperature within the urban forest typologies and the mobile transect traveled for analysis of the influence distance in summer and winter.

\subsection{Intensity of the influence in the immediate environment}

An analysis carried out to determine the intensity of influence that the different urban forest typologies exert on their surroundings found that there is variation between the typologies (Figure 5).
In general, we could infer that the temperature decrease provided by the urban forest at the edge $(0 \mathrm{~m})$ was $0.88^{\circ} \mathrm{C}$ on average; it was $0.66^{\circ} \mathrm{C}$ at $50 \mathrm{~m}$ distance, $0.45^{\circ} \mathrm{C}$ at $100 \mathrm{~m}, 0.34^{\circ} \mathrm{C}$ at $150 \mathrm{~m}$, and $0.30^{\circ} \mathrm{C}$ at $200 \mathrm{~m}$.

These results show that tree clusters exert an influence on a larger scale than a single tree. In a 


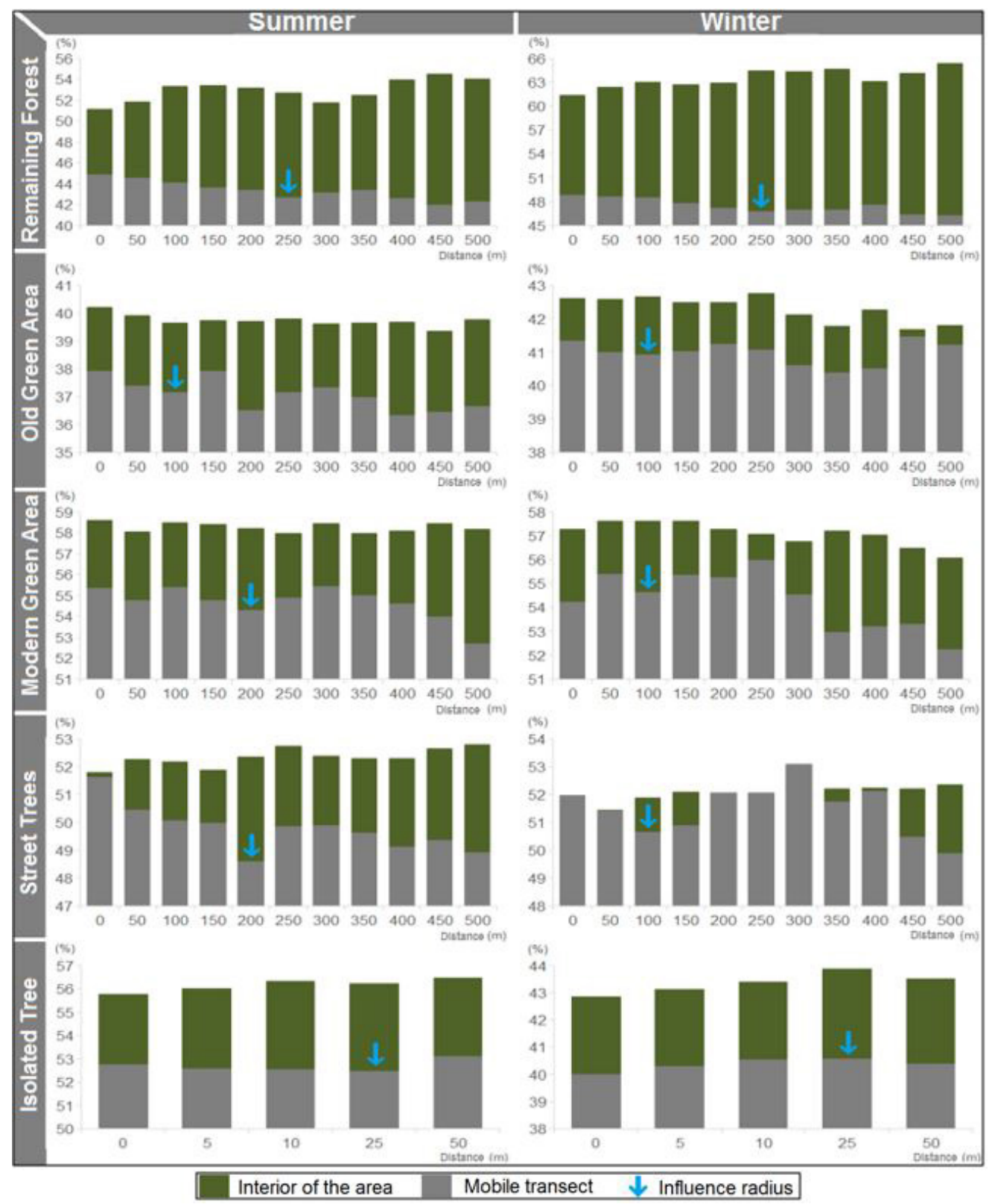

Figure 4. Relative air humidity within the urban forest typologies and the mobile transect traveled for analysis of the influence distance in summer and winter.

study of several species in the urban arborization of Campinas-SP, Abreu (2008) found that this influence occurs up to $15 \mathrm{~m}$ from the trunk. However, the author emphasizes that in any situation the results depend on specific characteristics of each species, such as canopy structure and density, size, shape and color of the leaves. Moreover, they argue that the tree species that have the greatest capacity to reduce the urban microclimate temperature are those with the greatest capacity to attenuate radiation and higher rates of evapotranspiration.

The analysis performed by season allowed us to verify some variability in the intensity of the influence that the urban forest exerts on its surroundings, both in temperature and relative humidity variables (Figure 6).

In the summer, the temperature decrease provided by the urban forest on its edge was on average $1^{\circ} \mathrm{C}$; 


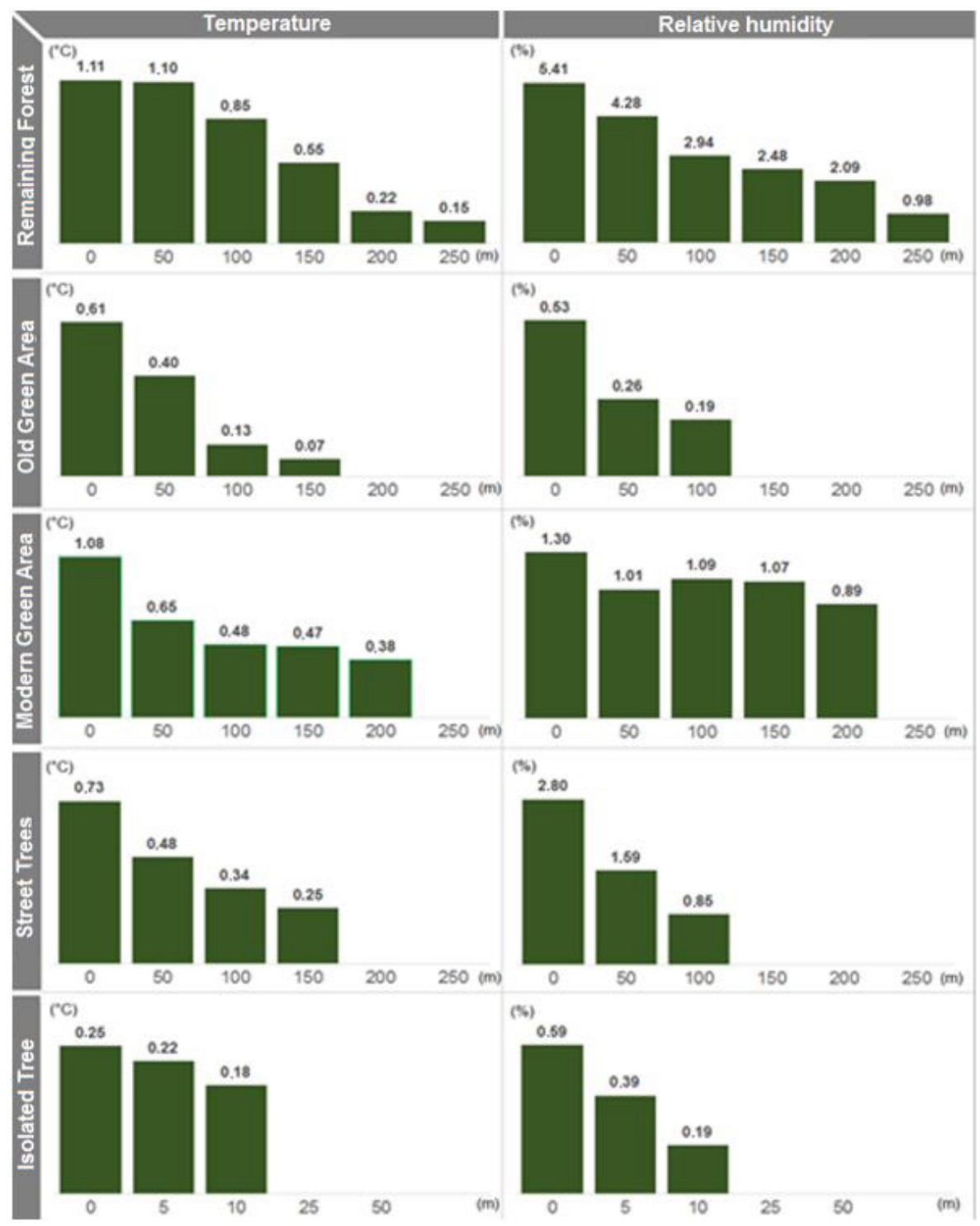

Figure 5. Intensity of influence of different urban forest typologies in the immediate environment.

it was $0.79^{\circ} \mathrm{C}$ at $50 \mathrm{~m}$ of distance, $0.42^{\circ} \mathrm{C}$ at $100 \mathrm{~m}$, $0.24^{\circ} \mathrm{C}$ at $150 \mathrm{~m}$, and $0.18^{\circ} \mathrm{C}$ at $200 \mathrm{~m}$. In the winter, the decrease in temperature at the edge was on average $0.92^{\circ} \mathrm{C}, 0.83^{\circ} \mathrm{C}$ at $50 \mathrm{~m}$ distance, $0.72^{\circ} \mathrm{C}$ at $100 \mathrm{~m}, 0.57^{\circ} \mathrm{C}$ at $150 \mathrm{~m}$, and $0.41^{\circ} \mathrm{C}$ at $200 \mathrm{~m}$.

For relative humidity, in the summer it was possible to observe that the increase of values provided by the urban forest (with all typologies studied) at the border $(0 \mathrm{~m})$ was on average 2.85 units; it was 1.61 units at $50 \mathrm{~m}$ distance, 1.51 units at $100 \mathrm{~m}$, and 0.95 units at $150 \mathrm{~m}$. In the winter, the relative humidity increase provided by the urban forest at the edge $(0 \mathrm{~m})$ was on average 2.40 units, 2.03 units at $50 \mathrm{~m}$ distance, and 1.32 units at $100 \mathrm{~m}$.

According to Honjo \& Takakura (1990), this cooling effect of green areas varies according to their size and proximity to other green areas. On the other hand, Cao et al. (2010) claim that this effect can extend beyond the park, by up to the width of the park, or even further. It can also reduce with an increase in the distance of the edge (Hamada \& Ohta, 2010).

The analysis according to the season of the year showed some variations, however it followed the same trend already presented. Overall, it was possible to affirm 


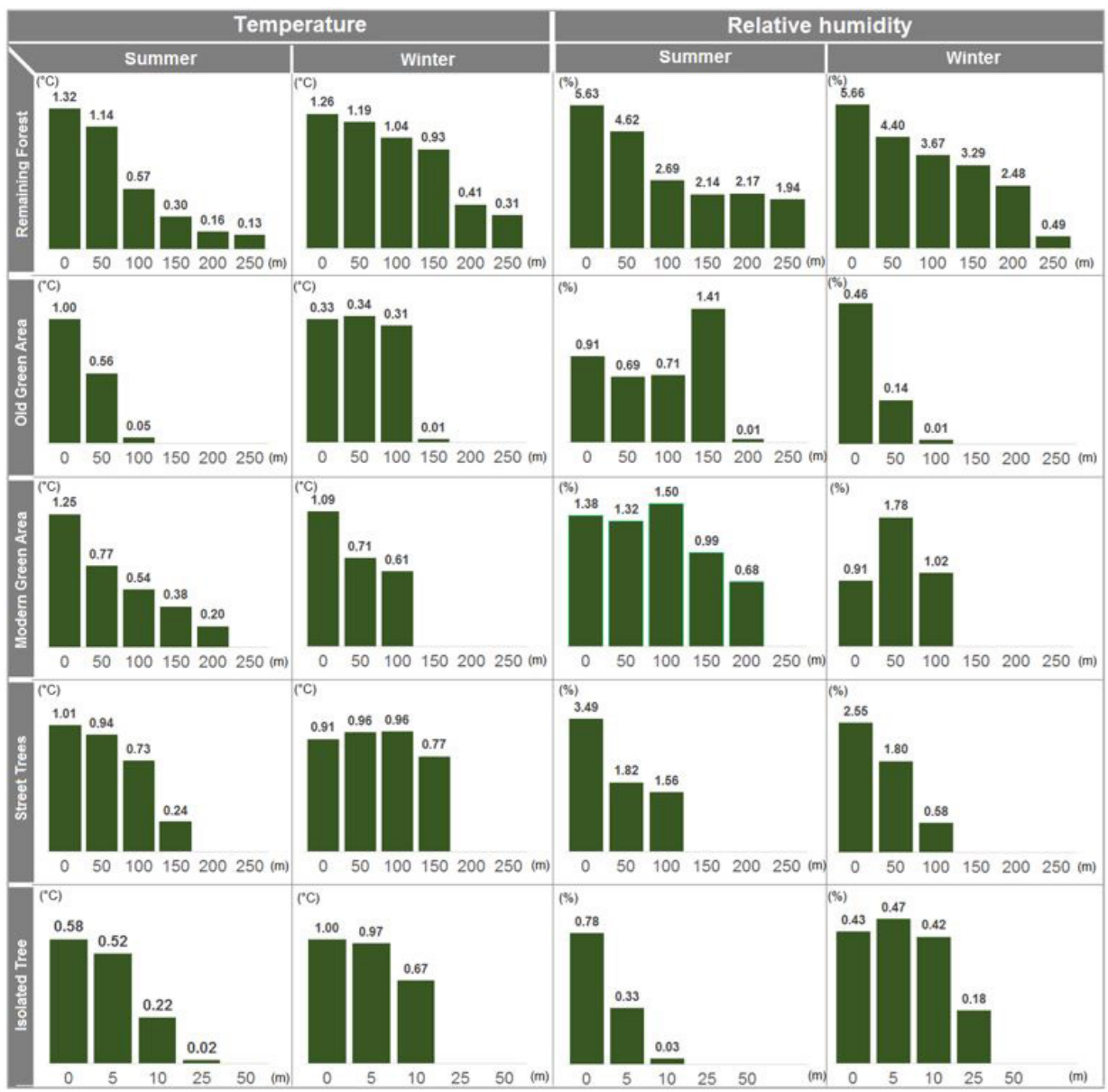

Figure 6. Intensity of influence of the different urban forest typologies in the immediate surroundings in summer and winter.

that Remaining Forest was the typology that exerted the greatest influence intensity on the microclimate around the area, followed by Modern Green Area and Street Trees.

Determining the intensity of influence was a difficult task, and several details regarding the urban morphology needed to be taken into account, in addition to having to consider the influence distance, which is difficult to determine in urban areas. For example, Dacanal (2011) did not observe a gradual warming of air temperature along mobile transects, a behavior that would demonstrate the direct relation of the temperature mitigation with the distance of the urban forest. Thus, it was concluded that other urban elements have an influence on the local climatic context, and may cancel out or intensify the mitigating effect of the green area, such as: wind susceptibility, site geometry and the thermal characteristics of the surface coating materials.

Furthermore, we could consider the density of the built area, ground cover, the building heights, the orientation and width of the streets which also influence the microclimatic variables due to the amount of solar radiation received (Shishegar, 2013). In this way, it is possible that the results will be different around green areas with wider streets, more intense vehicular traffic and more buildings, since these characteristics could even block the cooling flow of a green area (Hamada \& Ohta, 2010)

Finally, given the studies already developed and the detail used in the present investigation, we can affirm that the results found were satisfactory and consistent with reality. 


\section{CONCLUSION}

The influence distance that the urban forests exerted on their surroundings was $200 \mathrm{~m}$, except for the Isolated Trees typology where the influence distance in the summer was greater $(250 \mathrm{~m})$ than in the winter $(150 \mathrm{~m})$. Among the different typologies, the Remaining Forest exerted a microclimatic influence over a greater distance $(250 \mathrm{~m})$, followed by Modern Green Area (200 m), Old Green Area (150 m), Street Trees $(150 \mathrm{~m})$ and Isolated Trees (10 $\mathrm{m}$ for temperature and $25 \mathrm{~m}$ for relative humidity).

The intensity of influence that the urban forest exerted on the air temperature at a $50 \mathrm{~m}$ distance was $0.66^{\circ} \mathrm{C}$, while it was $0.45^{\circ} \mathrm{C}$ at $100 \mathrm{~m}, 0.34^{\circ} \mathrm{C}$ at $150 \mathrm{~m}$, and $0.30^{\circ} \mathrm{C}$ at $200 \mathrm{~m}$, always being more intense during the summer. The Remaining Forest was the typology that had the greatest influence, reaching $0.15^{\circ} \mathrm{C}$ at a distance of $250 \mathrm{~m}$.

\section{ACKNOWLEDGEMENTS}

To the Fundação Araucária de Apoio ao Desenvolvimento Científico e Tecnológico do Paraná for financing the purchase of equipment.

\section{SUBMISSION STATUS}

Received: 21 feb., 2017

Accepted: 22 june, 2017

\section{CORRESPONDE TO}

\section{Angeline Martini}

Departamento de Engenharia Florestal, Universidade Federal de Viçosa - UFV, Avenida Purdue, s/n, Edifício Reinaldo de Jesus Araújo, Campus Universitário, CEP 36570-900, Viçosa, MG, Brasil

e-mail: martini.angeline@gmail.com

\section{FINANCIAL SUPPORT}

Fundação Araucária de Apoio ao Desenvolvimento Científico e Tecnológico do Paraná.

\section{REFERENCES}

Abreu LV. Avaliação da escala de influência da vegetação no microclima por diferentes espécies arbóreas [dissertação]. Campinas: Faculdade de Engenharia Civil, Universidade Estadual de Campinas; 2008.

Adams MP, Smith PL. A systematic approach to model the influence of the type and density of vegetation cover on urban heat using remote sensing. Landscape and Urban Planning 2014; 132: 47-54. http://dx.doi.org/10.1016/j. landurbplan.2014.08.008.

Barros MP. Dimensão fractal e ilhas de calor urbanas: uma abordagem sistêmica sobre as implicações entre a fragmentação das áreas verdes e o ambiente térmico do espaço urbano [tese]. Cuiabá: Universidade Federal de Mato Grosso; 2012.

Biondi D, Batista AC, Martini A, Grise MM. O efeito microclimático do bosque Capão da Imbuia na cidade de Curitiba - PR, Brasil. In: Anais do V Congreso Forestal Latinoamericano; 2011; Lima. Lima: Facultad de Ciencias Forestales - UNA La Molina; 2011.

Brown RD, Vanos J, Kenny N, Lenzholzer S. Designing urban parks that ameliorate the effects of climate change. Landscape and Urban Planning 2015; 138: 118-131. http:// dx.doi.org/10.1016/j.landurbplan.2015.02.006.

Buyadi SNA, Wan Mohd WMN, Misni A. Quantifying green space cooling effects on the urban microclimate using remote sensing and gis techniques. In: Proceedings of the XXV International Federation of Surveyors; 2014; Kuala Lumpur. Kuala Lumpur: FIG; 2014. p. 1-16.

Cao X, Onishi A, Chen J, Imura H. Quantifying the cool island intensity of urban parks using ASTER and IKONOS data. Landscape and Urban Planning 2010; 96(4): 224-231. http://dx.doi.org/10.1016/j.landurbplan.2010.03.008.

Dacanal C. Fragmentos florestais urbanos e interações climáticas em diferentes escalas: estudos em Campinas, $S P$ [tese]. Campinas: Faculdade de Engenharia Civil, Arquitetura e Urbanismo, Universidade Estadual de Campinas; 2011.

Dimoudi A, Nikolopoulou M. Vegetation in the urban environment: microclimatic analysis and benefits. Energy and Building 2003; 35(1): 69-76. http://dx.doi.org/10.1016/ S0378-7788(02)00081-6.

Donovan GH, Butry DT. Trees in the city: valuing street trees in Portland, Oregon. Landscape and Urban Planning 2010; 94(2): 77-83. http://dx.doi.org/10.1016/j. landurbplan.2009.07.019.

Gartland L. Ilhas de calor: como mitigar zonas de calor em áreas urbanas. São Paulo: Oficina de Textos; 2010.

Giralt RP. Conforto térmico em espaços públicos abertos na cidade de Torres - RS [dissertação]. Porto Alegre: Faculdade de Arquitetura, Universidade Federal do Rio Grande do Sul; 2006. 
Hamada S, Ohta T. Seasonal variations in the cooling effect of urban green areas on surrounding urban areas. Urban Forestry \& Urban Greening 2010; 9(1): 15-24. http:// dx.doi.org/10.1016/j.ufug.2009.10.002.

Hamada S, Tanaka T, Ohta T. Impacts of land use and topography on cooling effect of green areas on surrounding urban areas. Urban Forestry \& Urban Greening 2013; 12(4): 426-434. http://dx.doi.org/10.1016/j.ufug.2013.06.008.

Honjo T, Takakura T. Simulation of thermal effects of urban green areas on their surrounding areas. Energy and Building 1990; 15(3-4): 443-446. http://dx.doi. org/10.1016/0378-7788(90)90019-F.

Huang L, Li J, Zhao D, Zhu J. A fieldwork study on the diurnal changes of urban microclimate in four types of ground cover and urban heat island of Nanjing, China. Building and Environment 2008; 43(1): 7-17. http://dx.doi. org/10.1016/j.buildenv.2006.11.025.

Instituto de Pesquisa e Planejamento Urbano de Curitiba - IPPUC. Desenvolvimento sustentável: indicadores de sustentabilidade de Curitiba - 2010. Curitiba: IPPUC; 2011.

Jiang B, Larsen L, Deal B, Sullivan WC. A dose-response curve describing the relationship between tree cover density and landscape preference. Landscape and Urban Planning 2015; 139: 16-25. http://dx.doi.org/10.1016/j. landurbplan.2015.02.018.

Jim CY, Lo AY, Byrne JA. Charting the green and climateadaptive city. Landscape and Urban Planning 2015; 138: 51-53. http://dx.doi.org/10.1016/j.landurbplan.2015.03.007.

Leal L, Martini A, Biondi D, Batista AC. Levantamento meteorológico expedito para análise da influência microclimática do Bosque Estadual João Paulo II. In: Anais do IV Encontro Sul-Brasileiro de Meteorologia; 2011; Pelotas. Pelotas: SBMET; 2011. p. 1-9.

Lee S-W, Hwang S-J, Lee S-B, Hwang H-S, Sung H-C. Landscape ecological approach to the relationships of land use patterns in watersheds to water quality characteristics. Landscape and Urban Planning 2009; 92(2): 80-89. http:// dx.doi.org/10.1016/j.landurbplan.2009.02.008.

Lin W, Yu T, Chang X, Wu W, Zhang Y. Calculating cooling extents of green parks using remote sensing: method and test. Landscape and Urban Planning 2015; 134: 66-75. http://dx.doi.org/10.1016/j.landurbplan.2014.10.012.

Martini A, Biondi D, Batista AC, Lima EM No. Microclima e conforto térmico de um fragmento florestal na cidade de Curitiba - PR, Brasil. In: Anais do V Congreso Forestal Latinoamericano; 2011; Lima. Lima: Facultad de Ciencias Forestales - UNA La Molina; 2011.

Martini A, Biondi D, Batista AC, Silva DF Fo. Validação da metodologia de transéctos móveis para coleta de dados microclimáticos no ambiente urbano. In: Anais do XI Simpósio Brasileiro de Climatologia Geográfica; 2014; Curitiba. Curitiba: ABCLIMA; 2014.

Mascaró L, Mascaró JJ. Ambiência urbana. 3. ed. Porto Alegre: +4 Editora; 2009.

Nascimento DTF, Oliveira IJ. Análise da evolução do fenômeno de ilhas de calor no município de Goiânia/ GO (1986 - 2010). Boletim Goiano de Geografia 2011; 31(2): 113-127.

Raskovic S, Decker R. The influence of trees on the perception of urban squares. Urban Forestry \& Urban Greening 2015; 14(2): 237-245. http://dx.doi.org/10.1016/j. ufug.2015.02.003.

Shashua-Bar L, Hoffman ME. Vegetation as a climatic component in the design of an urban street. An empirical model for predicting the cooling effect of urban green areas with trees. Energy and Building 2000; 31(3): 221235. http://dx.doi.org/10.1016/S0378-7788(99)00018-3.

Shishegar N. Street design and urban microclimate: analyzing the effects of street geometry and orientation on airflow and solar access in urban canyons. Journal of Clean Energy Technologies 2013; 1: 52-53. http://dx.doi. org/10.7763/JOCET.2013.V1.13.

Thundiyil KA. Rising temperatures and expanding megacities: improving air quality in Mexico City through urban heat island mitigation [thesis]. Ann Arbor: Massachusetts Institute of Technology; 2003.

Yu C, Hien WN. Thermal benefits of city parks. Energy and Building 2006; 38(2): 105-120. http://dx.doi.org/10.1016/j. enbuild.2005.04.003. 